\title{
Pengaruh Supportive Educative Nursing Intervention (SENI) terhadap Pengetahuan dan Sikap Penyintas Kanker Payudara
}

\author{
Jajang Ganjar Waluya ${ }^{1}$, Laili Rahayuwati², Mamat Lukman ${ }^{2}$ \\ ${ }^{1}$ Puskesmas Cipanas, ${ }^{2}$ Fakultas Keperawatan, Universitas Padjadjaran \\ Email: jajang17001@ @ail.unpad.ac.id
}

\begin{abstract}
Abstrak
Kanker payudara merupakan salah satu jenis kanker terbanyak di Indonesia. Tingginya angka kejadian dan kematian oleh kanker payudara menunjukkan kanker payudara membutuhkan perhatian dan penanganan serius. Penelitian mengungkapkan aktivitas fisik penyintas kanker payudara berkurang secara signifikan setelah diagnosis kanker payudara. Diagnosis kanker adalah "teachable moment" yang memungkinkan dengan edukasi dan dukungan yang tepat dapat membantu penyintas kanker payudara mempertahankan atau bahkan meningkatkan tingkat aktivitas mereka. Penelitian ini untuk mengidentifikasi pengaruh Supportive Educative Nursing Intervention (SENI) terhadap pengetahuan, sikap dan intensitas aktivitas fisik penyintas kanker payudara. Jenis penelitian ini adalah kuantitatif dengan desain quasi experiment. Rancangan yang digunakan adalah pre-test and post-test with control group (quasy experiment with control). Jumlah sampel sebanyak 61 orang yang terbagi menjadi dua kelompok yaitu kelompok intervensi (30 orang) dan kelompok kontrol (31 orang). Hasil analisis menunjukkan terdapat pengaruh signifikan SENI terhadap pengetahuan ( $p$ value $=0,000)$ dan sikap ( $p$-value $=0,000)$ penyintas kanker payudara tentang aktivitas fisik. SENI memberikan pengaruh signifikan terhadap pengetahuan dan sikap penyintas kanker payudara tentang aktivitas fisik. Rumah singgah dapat mengadakan program untuk meningkatkan aktivitas fisik penyintas seperti senam bersama yang disesuaikan dengan kondisi di rumah singgah. Dinas kesehatan kota Bandung perlu memfasilitasi pelatihan bagi pengelola rumah singgah dalam hal kesehatan olahraga sebagai upaya peningkatan sosialisasi kesehatan olahraga bagi penghuni rumah singgah.
\end{abstract}

Kata kunci: Aktivitas fisik, kanker payudara, pengetahuan, sikap, supportive educative nursing intervention.

\begin{abstract}
Breast cancer is one of the most types of cancer in Indonesia. The high incidence and death by breast cancer shows that breast cancer requires serious treatment. The study revealed the physical activity of survivors of breast cancer significantly reduced after a diagnosis of breast cancer. The diagnosis of cancer is 'teachable moment' which allows the right education and support to help survivors of breast cancer to maintain or even increase their level of physical activity. This study was to examine the effect of Supportive Educative Nursing Intervention (SENI) on the knowledge, attitudes and intensity of breast cancer survivors' physical activity. This type of research is quantitative with a quasi experiment design. The design used is pre-test and post-test with control group (quasi experiment with control). The total of samples was 61 people, divided into two groups, the intervention group (30 people) and the control group (31 people). The analysis showed there was a significant effect of SENI on knowledge ( $p$-value $=0,000)$ and attitude $(p$-value $=0,000)$ of breast cancer survivors about physical activity. SENI has a significant influence on breast cancer survivors' knowledge and attitudes about physical activity. Shelter homes can be held programs to increase the physical activity of survivors such as joint gymnastics which is adjusted to the conditions at the shelter house. Bandung City Health Office needs to facilitate training for managers of shelter house in terms of sports health as an aid to improving health socialization for residents of shelter house.
\end{abstract}

Keywords: Attitude, breast cancer, knowledge, supportive educative nursing intervention, physical activity. 


\section{Pendahuluan}

Kemajuan dalam diagnosis dini dan pengobatan kanker berdampak terhadap peningkatan kelangsungan hidup penyintas kanker. Penyintas (survivor) pada kanker adalah setiap orang yang telah didiagnosis kanker dan masih hidup, baik yang sudah menyelesaikan terapinya maupun yang sedang dan akan terapi (American Cancer Society, 2016). Menurut Rock et al (2012) perjalanan penyintas kanker ditandai dengan 3 fase umum yaitu pengobatan aktif dan pemulihan, kehidupan setelah pemulihan termasuk penyintas yang bebas penyakit atau yang memiliki penyakit stabil, dan kanker stadium lanjut dan akhir kehidupan.

World Cancer Research Fund (2018) mengeluarkan rekomendasi bagi penyintas kanker yang sudah berhasil menjalani pengobatan untuk tetap menjaga pola hidup sehat dengan meningkatkan aktivitas fisik dan menjaga berat badan ideal. Untuk itu kebutuhan menerapkan pola hidup sehat termasuk aktivitas fisik pada penyintas kanker menjadi sangat penting.

Aktivitas fisik adalah setiap gerakan tubuh yang dihasilkan oleh otot rangka yang memerlukan pengeluaran energi dilakukan sepanjang hari berkisar dari aktivitas sehari hari, gaya hidup hingga olahraga (WHO, 2010). Aktivitas fisik secara luas diakui sebagai terapi non-farmakologis yang efektif pada pasien kanker (Fong et al., 2012). Semakin banyak bukti mendukung gagasan bahwa peningkatan aktivitas fisik memberikan manfaat penting untuk meningkatkan hasil psikologis dan kesejahteraan fisik pada pasien kanker.

Laporan terbaru dari World Cancer Research Fund (2018) menyebutkan terdapat bukti kuat bahwa aktivitas fisik (intensitas sedang atau kuat) melindungi terhadap kanker payudara, usus besar dan endometrium. Aktivitas fisik dengan intensitas kuat dapat melindungi terhadap kanker payudara premenopause (World Cancer Research Fund, 2018). Riset lain juga membuktikan bahwa aktivitas fisik dapat menurunkan kematian pada penyintas kanker payudara dan kolorektal (Ballard-Barbash et al., 2012). Penelitian oleh Speck et al (2010) memperlihatkan bahwa aktivitas fisik dikaitkan dengan kesehatan psikologis penyintas kanker yang lebih baik.

Berdasarkan penelitian Rock et al. (2012) aktivitas fisik setelah diagnosis kanker dapat mengurangi risiko kekambuhan di antara beberapa kelompok penyintas kanker termasuk kanker payudara, kolorektal, prostat, dan ovarium. Meta-analisis lain dari 6 studi kohort prospektif yang mencakup lebih dari 12.000 penderita kanker payudara menunjukkan bahwa aktivitas fisik pasca diagnosis secara konsisten dapat menurunkan 
risiko kematian akibat kanker payudara sebesar 34\% dan menurunkan risiko kambuh sebesar 24\% (Rock et al., 2012).

Melihat banyaknya bukti ilmiah keuntungan aktivitas fisik bagi penyintas kanker payudara, para ahli mengembangkan dan menguji program latihan untuk mendorong penyintas kanker ikut berpartisipasi dalam aktivitas fisik. Sebagian besar penelitian tentang aktivitas fisik pada pasien kanker dilakukan pada pasien kanker payudara (Fong et al., 2012). Program tersebut diantaranya pemberian modul aktivitas fisik dan pedometer, rekomendasi dari ahli onkologi, saran latihan, dan pendidikan olahraga telah berhasil memotivasi pasien untuk meningkatkan jumlah aktivitas fisik mereka. Salah satu faktor penting dalam upaya peningkatan partisipasi aktivitas fisik penyintas kanker payudara adalah dengan edukasi, konseling dan dukungan dari masyarakat (Patrick, Pratt, \& Sallis, 2009).

Meskipun hasil riset memperlihatkan efek positif dari aktivitas fisik terhadap kelangsungan hidup penyintas kanker payudara, dan beberapa program telah berhasil meningkatkan aktivitas fisik mereka namun data menunjukkan bahwa tingkat aktivitas fisik penyintas kanker berkurang secara signifikan setelah diagnosis kanker payudara. Rata-rata, aktivitas fisik menurun sebesar $11 \%$ dengan kehilangan sekitar 2 jam per minggu aktivitas fisik di rumah dan aktivitas fisik terkait olahraga (Carmichael et al., 2011). Sebuah penelitian dari Amerika Serikat melaporkan bahwa hanya 32\% dari penyintas kanker payudara berpartisipasi dalam tingkat aktivitas fisik yang disarankan yaitu 150 menit per minggu aktivitas fisik intensitas sedang hingga kuat baik aktivitas fisik rekreasi maupun olahraga (Carmichael et al., 2011).

Sebuah studi dari 2.885 penyintas kanker payudara yang terdaftar di American Cancer Society SCS-II cohort juga menunjukkan bahwa hanya 37\% wanita yang memenuhi rekomendasi pedoman aktivitas fisik (Blanchard, Courneya, \& Stein, 2008). Riset lain memperlihatkan penyintas kanker payudara berada dalam keadaan kurang aktif bahkan tidak aktif. Survei di Inggris menunjukkan bahwa 37\% penyintas kanker tidak aktif secara fisik sama sekali (Hancock, 2012). Penelitian lain juga mengungkapkan lebih dari dua pertiga penyintas kanker adalah kurang aktif (Blanchard, Courneya, \& Stein, 2008). Namun, menurut Blanchard et al., (2008) diagnosis kanker adalah 'teachable moment' yang memungkinkan dengan edukasi dan dukungan yang tepat dapat membantu penyintas kanker payudara untuk mempertahankan atau bahkan meningkatkan tingkat aktivitas mereka (Blanchard et al., 2008). 
Keadaan tersebut menimbulkan pertanyaan apakah edukasi aktivitas fisik bagi penyintas kanker yang diberikan oleh perawat sudah tepat, kalaupun sudah diberikan edukasi yang tepat lantas kenapa penyintas kanker masih tidak aktif?. Hal tersebut menimbulkan pertanyaan sekaligus memberikan keyakinan penulis bahwa metode edukasi yang selama ini diberikan belum tepat sehingga dibutuhkan upaya edukasi lain untuk meningkatkan pengetahuan dan sikap yang pada akhirnya akan mendorong penyintas kanker payudara untuk lebih aktif. Ini menunjukkan bahwa mungkin penting untuk mengembangkan intervensi edukasi model lain.

Ide pengembangan strategi edukasi bagi penyintas kanker sebenarnya sudah direkomendasikan oleh para ahli. Riset di Inggris menyoroti perlunya strategi edukasi yang bertujuan untuk mempromosikan aktivitas fisik dalam konsultasi perlu ditargetkan secara luas di kalangan komunitas dokter kanker (Daley, Bowden, Rea, Billingham, \& Carmicheal, 2008). Edukasi kesehatan pada penyintas kanker sangat penting karena pengetahuan pasien tentang kanker sangat terbatas. Sumber informasi untuk pengobatan umumnya dilakukan melalui proses pencarian secara mandiri oleh keluarga baik melalui televisi, media maupun pencarian di internet. Selain itu hampir tidak pernah pasien mengetahui seluk beluk kanker dengan lebih detail. Informasi lain tentang kanker mereka dapatkan juga dari sumber yang dianggap dipercaya seperti, suami, saudara, teman maupun tetangga. Ada juga yang menanyakan masalah penyakitnya dan proses pengobatan kepada dokter dan perawat namun sedikit pasien yang puas dengan jawaban yang diberikan (Rahayuwati, Ibrahim, \& Komariah, 2017).

Penelitian Kristel et al.(2012) di Rumah Sakit Hasan Sadikin Bandung pada pasien kanker payudara yang menjalani kemoterapi dalam hal pemenuhan developmental self-care requisites dibutuhkan dukungan edukasi dari perawat (Kristel, Anna, \& Priambodo, 2012). Penelitian lain juga menyarankan penyediaan layanan konseling pada penyintas kanker payudara post mastektomi (Tasripiyah, Prawesti, \& Rahayu, 2012). Penelitian Kadar dan Patellongi (2017) juga menyampaikan hasil bahwa kebutuhan informasi kesehatan pada penyintas kanker payudara sebagian besar tidak terpenuhi. Penelitian ini menyimpulkan bahwa kebutuhan fisik dan aktifitas sehari-hari pada 95\% survivor kanker payudara secara umum tidak terpenuhi .

Supportive Educative Nursing Intervention (SENI) merupakan bagian dari Orem's nursing system yaitu suatu metode edukasi yang menggunakan berbagai metode seperti teaching, guiding, supporting, dan providing environment yang akan berkonstribusi 
penting dalam self care agency. Secara umum tujuan edukasi suportif adalah membantu individu melakukan tindakan perawatan diri (Parker, 2005). Edukasi suportif berbeda dengan edukasi kesehatan pada umumnya karena bukan hanya aspek kognitif pasien yang ditingkatkan, namun juga berfokus pada pengajaran, bimbingan, dukungan dan menyediakan lingkungan yang kondusif bagi pasien (Kafil, Ropi, \& Rahayu, 2018).

SENI merupakan intervensi keperawatan yang terencana dan terarah yang mungkin dapat mendukung penyintas kanker meningkatkan pengetahuan, sikap dan keterampilan latihan fisik selama atau pasca pengobatan kanker. Hasil yang diharapkan dari edukasi suportif ini adalah adanya perubahan perilaku penyintas kanker untuk lebih aktif secara fisik melalui format sistematik dan terstruktur sesuai dengan prinsip-prinsip edukasi.

Berdasarkan uraian di atas, peneliti tertarik untuk mengadakan penelitian apakah Supportive Educative Nursing Intervention (SENI) dapat meningkatkan pengetahuan dan sikap penyintas kanker payudara tentang aktivitas fisik?. Tujuan umum penelitian ini adalah untuk mencari pengaruh SENI terhadap pengetahuan dan sikap penyintas kanker payudara tentang aktivitas fisik.

\section{Metode}

Jenis penelitian ini adalah kuantitatif dengan desain quasi experiment yang bertujuan untuk mengetahui pengaruh Supportive Educative Nursing Intervention terhadap pengetahuan dan sikap penyintas kanker payudara tentang aktivitas fisik. Rancangan yang digunakan adalah pre-test and post-test with control group (quasy experiment with control).

Populasi dalam penelitian ini adalah seluruh penyintas kanker payudara yang berada di Rumah Singgah Kanker yang berada di Kecamatan Sukajadi Kota Bandung dan Kecamatan Baleendah Kabupaten Bandung pada tahun 2019. Jumlah keseluruhan penyintas kanker payudara yang berada di 7 Rumah Singgah Kanker tersebut sejak 1 Januari sampai dengan 20 Mei 2019 adalah sebanyak 75 penyintas kanker payudara. Teknik pengambilan sampel dalam penelitian ini adalah non probability sampling dengan pendekatan purposive sampling. Pemilihan sampel dengan menentukan sifat-sifat subjek seperti tertera dalam kriteria inklusi. Kelompok intervensi adalah penyintas kanker payudara yang berada di Rumah Teduh, Rumah Singgah Sehat Sejahtera dan Rumah Singgah Pasien IZI. Sedangkan kelompok kontrol adalah penyintas kanker payudara yang berada di Rumah Singgah Daarut Tauhid, Rumah Singgah Sedekah Rombongan, Rumah Teduh 9 dan Rumah Teduh 10 Baleendah. 
Perhitungan besar sampel berdasarkan rumus dari Dahlan (2013). Simpangan baku 3,8 dengan selisih mean $\bar{X}_{1}-\bar{X}_{2}$ adalah 2,0 berdasarkan penelitian yang dilakukan oleh Mohammadpour, et al (2015). Penelitian ini menggunakan Confidence Interval $=95 \%(\alpha<$ 0.05) dan power test $80 \%$. Nilai nilai $\alpha$ (95\%) dan $\beta$ (80\%) merujuk pada Dahlan (2013) yaitu nilai $\mathrm{Z}_{\alpha}=1.64$ sementara untuk nilai $\mathrm{Z}_{\beta}=1,28$ sehingga besar sampel dapat ditentukan dengan rumus :

$$
\begin{aligned}
\mathrm{n} & =\left[\frac{\left(\mathrm{Z}_{\alpha}+\mathrm{Z}_{\beta}\right) \mathrm{S}}{\bar{X}_{1}-\bar{X}_{2}}\right]^{2} \\
& =\left[\frac{(1,64+1,28) \times 3,8}{2}\right]^{2} \\
& =30,78 \text { (dibulatkan menjadi 31) }
\end{aligned}
$$

Untuk menghindari drop out maka besar sampel tersebut ditambahkan dengan $10 \%$ sehingga jumlah sampel menjadi 34 untuk masing-masing kelompok.

Kriteria inklusi untuk kelompok intervensi maupun kelompok kontrol dalam penelitian ini yaitu

1) Penyintas kanker payudara yang sedang/sudah menjalani pengobatan baik pembedahan atau terapi radiasi atau kemoterapi.

2) Rentang usia 18-69 tahun

3) Berada di Rumah Singgah kanker

4) Bisa baca dan tulis serta bersedia menjadi responden

5) Mengikuti pretest dan posttest

Kriteria ekslusi dalam penelitian ini adalah

1) Tidak bisa mengikuti seluruh program intervensi

2) Penyintas kanker payudara dengan gangguan pendengaran dan penglihatan.

3) Kondisi lemah dan tidak bisa berpartisipasi dalam kegiatan penelitian. 


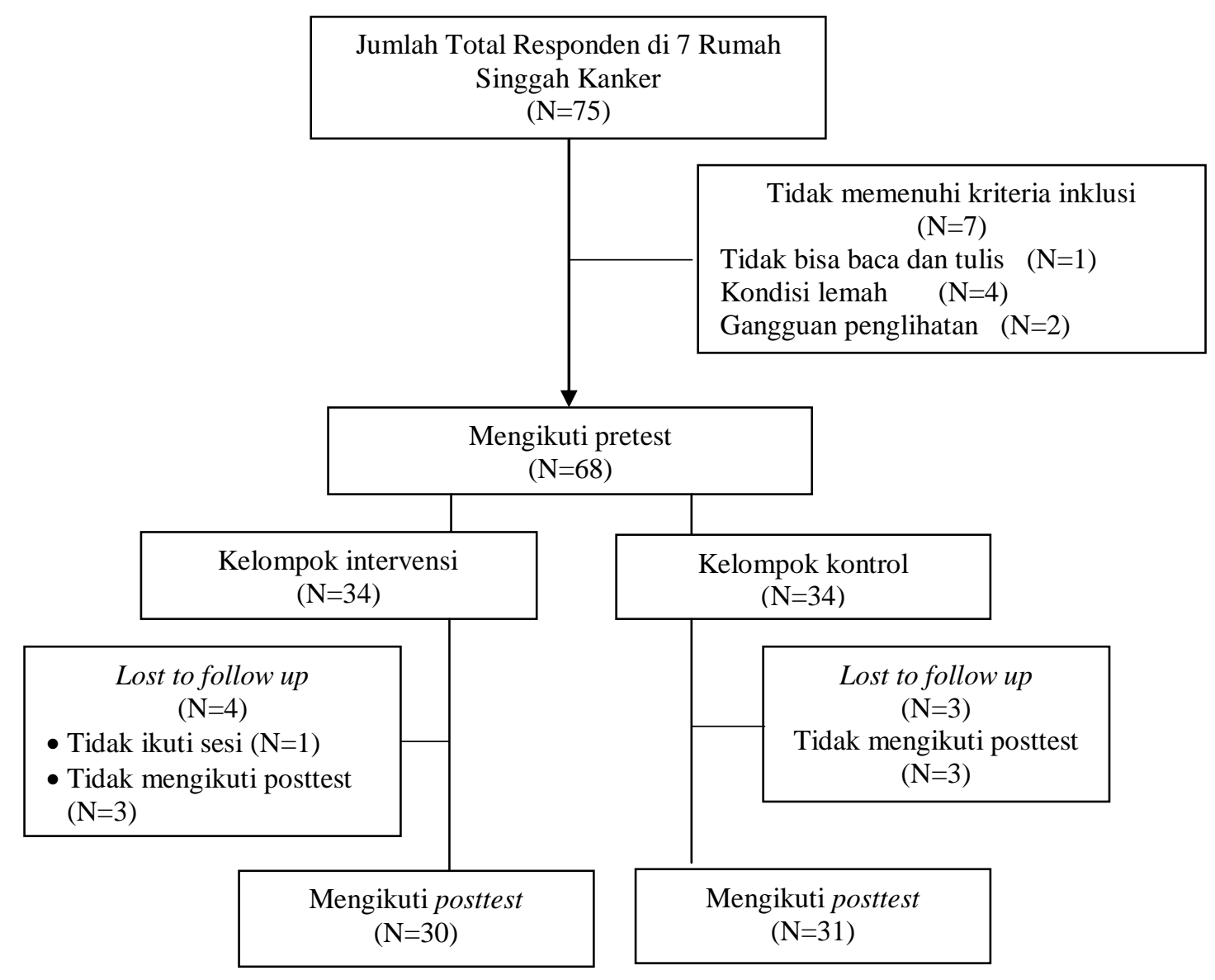

\section{Gambar 1 Skema Penentuan Kelompok Responden}

Penelitian ini bertempat di 7 rumah singgah kanker di Kecamatan Sukajadi dan Kecamatan Baleendah Kota Bandung yaitu Rumah Teduh (1-8), Rumah Singgah Sehat Sehatera, Rumah Singgah Sedekah Rombongan, Rumah Singgah Daarut Tauhid, Rumah Singgah Pasien IZI, Rumah Teduh 9 dan Rumah Teduh 10 Baleendah. Pelaksanaan pengambilan data dimulai pada tanggal 3 Mei sampai dengan 25 Juni 2019. 


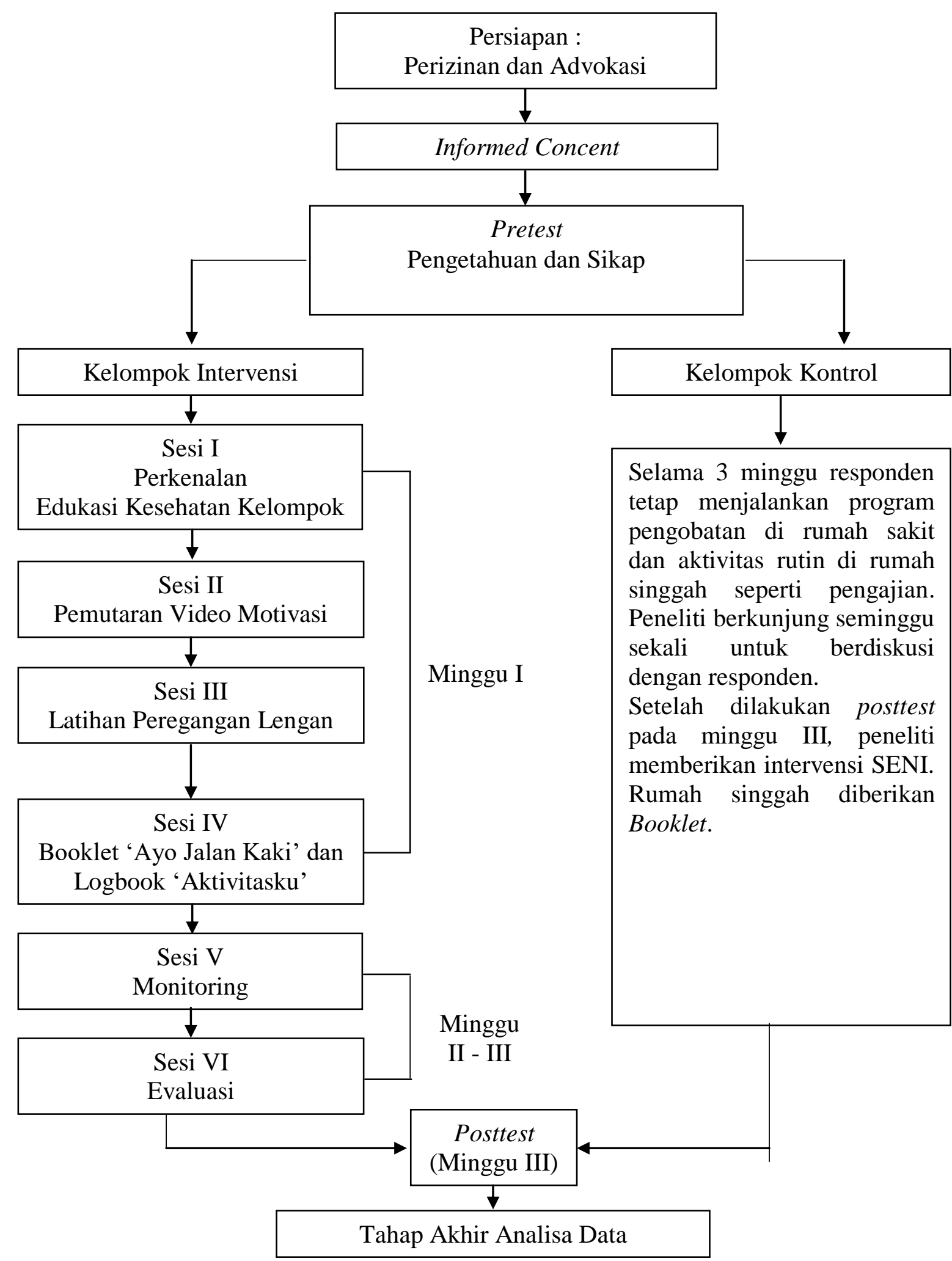

Gambar 2 Prosedur Penelitian 
Protokol pelaksanaan SENI terdari dari enam sesi yang diuraikan sebagai berikut:

1) Sesi I (Hari kesatu minggu I)

Pada sesi I intervensi SENI adalah diawali orientasi yaitu dengan perkenalan peneliti dengan responden dan perkenalan antar anggota kelompok. Kegiatan orientasi berlangsung selama 15 menit. Dilanjutkan dengan edukasi kesehatan kelompok sebagai bagian dari pengajaran (teaching) dari intervensi SENI. Edukasi kesehatan kelompok berlangsung selama 30 menit. Pada setiap akhir sesi dilaksanakan evaluasi dari intervensi. Sesi I ini berlangsung 45 menit (Mohammadpour et al., 2015).

2) Sesi II (Hari kesatu minggu I)

Pada sesi kedua diadakan pemutaran video motivasi aktivitas fisik. Video motivasi yang diputar dengan judul 'Meningkatkan Aktivitas Fisik' dari Pusat Promosi Kesehatan Kemenkes RI. Setelah pemutaran video dilanjutkan dengan diskusi tanya jawab. Sesi II berlangsung 20 menit.

3) Sesi III (Hari kedua minggu I)

Pada sesi III diadakan latihan peregangan lengan bagi penyintas kanker payudara. Latihan peregangan lengan adalah gerakan gerakan secara bertahap untuk menjaga stabilitas fisik dan psikis penyintas kanker payudara yang telah menjalani operasi. Tujuan yang telah ditentukan berdasarkan pada Pedoman Nasional Tata Laksana Kanker Payudara Peserta dari Kemenkes RI, (2018). Kegiatan diawali dengan pemutaran video latihan peregangan lengan dilanjutkan dengan latihan yang diikuti oleh seluruh peserta. Peneliti memberikan bimbingan dan mendampingi peserta selama latihan. Sesi III berlangsung 45 menit.

4) Sesi IV (Hari kedua minggu I)

Sesi IV penjelasan tentang booklet 'Ayo Jalan Kaki' dan logbook 'Aktivitasku'. Tiap peserta akan mendapatkan satu buah booklet dan satu logbook. Sesi IV berlangsung selama 30 menit.

5) Sesi V (Monitoring, Minggu II-III)

Pada sesi kelima penelitian ini merupakan tahap monitoring untuk peserta SENI setelah mengikuti sesi I hingga IV. Pada sesi ini dilakukan pemantauan catatan logbook dari peserta. Peneliti melakukan evaluasi langsung kepada peserta tentang aktivitas fisik yang sudah dijalankan yang tercatat dalam logbook dan memberikan apresiasi. Sesi $\mathrm{V}$ berlangsung 2 minggu (minggu II-III) dengan 
frekuensi kunjungan atau sambungan telepon sekali dalam seminggu selama 30 hingga 45 menit untuk membimbing dan mendukung peserta.

6) Sesi VI (Evaluasi)

Sesi keenam adalah evaluasi. Peneliti melakukan evaluasi langsung kepada peserta tentang aktivitas fisik yang sudah dijalankan yang tercatat dalam logbook dan memberikan apresiasi. Evaluasi dilaksanakan bersamaan dengan posttest yaitu pada minggu III. Sesi VI berlangsung 60 menit.

Hasil

Tabel 1 Distribusi Frekuensi Karakteristik Responden pada Kelompok Intervensi dan Kontrol (N=61)

\begin{tabular}{|c|c|c|c|c|c|}
\hline \multirow{3}{*}{ Karakteristik } & \multicolumn{4}{|c|}{ Kelompok } & \multirow{3}{*}{$p$-Value } \\
\hline & \multicolumn{2}{|c|}{$\begin{array}{l}\text { Intervensi } \\
(\mathrm{N}=30)\end{array}$} & \multicolumn{2}{|c|}{$\begin{array}{l}\text { Kontrol } \\
(\mathrm{N}=31)\end{array}$} & \\
\hline & $\mathrm{N}$ & $\%$ & $\mathrm{~N}$ & $\%$ & \\
\hline \multicolumn{6}{|l|}{ Pendidikan } \\
\hline SD & 23 & 76,7 & 21 & 67,7 & \multirow{3}{*}{$0,780^{\mathrm{b}}$} \\
\hline SMP & 3 & 10,0 & 5 & 16,1 & \\
\hline SMA & 4 & 13,3 & 5 & 16,1 & \\
\hline \multicolumn{6}{|l|}{ Status Perkawinan } \\
\hline Belum Menikah & 1 & 3,3 & 0 & 0 & \multirow{3}{*}{$0,473^{b}$} \\
\hline Menikah & 26 & 86,7 & 25 & 80.6 & \\
\hline Janda & 3 & 10,0 & 6 & 19,4 & \\
\hline \multicolumn{6}{|l|}{ Pekerjaan } \\
\hline IRT & 28 & 93,3 & 31 & 100 & \multirow{3}{*}{$0,238^{b}$} \\
\hline Bekerja & 1 & 3,3 & 0 & 0 & \\
\hline Pelajar & 1 & 3,3 & 0 & 0 & \\
\hline \multicolumn{6}{|l|}{ Stadium kanker } \\
\hline I & 1 & 3,3 & 0 & 0 & \multirow{4}{*}{$0,457^{b}$} \\
\hline II & 9 & 30,0 & 12 & 38,7 & \\
\hline III & 15 & 50,0 & 17 & 54,8 & \\
\hline IV & 5 & 16,7 & 2 & 6,5 & \\
\hline \multicolumn{6}{|l|}{ Pengobatan saat ini } \\
\hline Post Operasi & 1 & 3,3 & 0 & 0 & \multirow{3}{*}{$0,582^{b}$} \\
\hline Kemoterapi & 21 & 70,0 & 20 & 64,5 & \\
\hline Radioterapi & 8 & 26,7 & 11 & 35,5 & \\
\hline Usia (Tahun) & $\begin{array}{l}\text { Mean: } \\
46,97\end{array}$ & & $\begin{array}{l}\text { Mean: } \\
45,84\end{array}$ & & $0,697^{a}$ \\
\hline
\end{tabular}

Keterangan : a : independent sample t test, $\mathrm{b}:$ fisher's exact

Berdasarkan tabel 1, dapat diuraikan tentang karakteristik responden dengan tingkat pendidikan terbesar adalah Sekolah Dasar (SD) yaitu sebesar 76,7\% pada kelompok 
intervensi dan untuk kelompok kontrol sebesar 67,7\%. Status perkawinan sebagian besar responden sudah menikah atau yaitu sebesar $86,7 \%$ pada kelompok intervensi sementara pada kelompok kontrol sebesar 80,6\%. Mayoritas responden adalah ibu rumah tangga yaitu sebesar 93,3\% pada kelompok intervensi dan $100 \%$ pada kelompok kontrol.

Stadium kanker payudara yang dialami responden sebagian besar adalah stadium III baik pada kelompok intervensi maupun kelompok kontrol yaitu sebesar $50 \%$ pada kelompok intervensi dan 54,8\% pada kelompok kontrol. Pengobatan yang sedang dijalani responden sebagian besar kemoterapi yaitu sebesar $70 \%$ pada kelompok intervensi dan kelompok kontrol yaitu 64,5\%. Responden berusia rata-rata 47 tahun pada kelompok intervensi dan rata-rata 46 tahun pada kelompok kontrol.

Berdasarkan tabel 1, hasil analisis kesetaraan tingkat pendidikan diperoleh $p$-value $=$ 1,000. Karena nilai $p$-value $=1,000>0,05$ maka dapat disimpulkan data tingkat pendidikan responden antara kelompok intervensi dan kelompok kontrol adalah homogen. Hasil analisis kesetaraan usia, status perkawinan, pekerjaan, stadium kanker, pengobatan yang dijalani menunjukkan nilai Sig. > 0.05 yang berarti bahwa karakteristik responden antara kelompok intervensi dan kelompok kontrol adalah homogen.

Tabel 2 Rata-rata pengetahuan dan sikap sebelum dan sesudah intervensi pada kelompok intervensi dan kelompok kontrol

\begin{tabular}{|c|c|c|c|c|c|c|c|c|}
\hline \multirow[b]{3}{*}{ Varibel } & \multirow[b]{3}{*}{$\begin{array}{l}\text { Time } \\
\text { Point }\end{array}$} & \multicolumn{6}{|c|}{ Kelompok } & \multirow[b]{3}{*}{$p$-Value } \\
\hline & & \multicolumn{3}{|c|}{ Intervensi } & \multicolumn{3}{|c|}{ Kontrol } & \\
\hline & & Mean & SD & $p-$ Value $^{\mathrm{b}}$ & $\begin{array}{c}M e a \\
n\end{array}$ & SD & $\underset{\substack{p-\\
\text { Value }}}{c}$ & \\
\hline \multirow{2}{*}{$\begin{array}{l}\text { Pengetahua } \\
\mathrm{n}\end{array}$} & Pre test & 8,8 & 2,4 & \multirow[t]{2}{*}{0,000} & 8,2 & 2,8 & \multirow[t]{2}{*}{0,209} & 0,348 \\
\hline & $\begin{array}{l}\text { Post } \\
\text { test }\end{array}$ & 11,7 & 1,8 & & 8,5 & 2,8 & & 0,000 \\
\hline \multirow[t]{2}{*}{ Sikap } & Pre test & 38,5 & 4,2 & \multirow[t]{2}{*}{0,000} & 37,8 & 4,5 & \multirow[t]{2}{*}{0,858} & 0,513 \\
\hline & $\begin{array}{l}\text { Post } \\
\text { test }\end{array}$ & 43,1 & 3,4 & & 38,0 & 3,9 & & 0,000 \\
\hline Keterangan : & $\begin{array}{l}{ }^{\mathrm{b}} \text { Paired-s }-\mathrm{s} \\
{ }^{\mathrm{c}} \text { Indepen }\end{array}$ & plest t-t & test & & & & & \\
\hline
\end{tabular}

Berdasarkan tabel 2 diketahui nilai signifikansi pengetahuan pada kelompok intervensi adalah sebesar ( $p$-value $=0,000)$, yang berarti terdapat perbedaan rata-rata pengetahuan pada kelompok intervensi antara sebelum intervensi dengan sesudah intervensi. Maka dapat disimpulkan ada pengaruh Supportive Educative Nursing Intervention dalam meningkatkan pengetahuan penyintas kanker payudara tentang aktivitas fisik. Sedangkan nilai signifikansi pengetahuan pada kelompok kontrol adalah sebesar ( $p$ - 
value $=0,209)$ yang berarti tidak terdapat perbedaan rata-rata pengetahuan pada kelompok kontrol antara sebelum dengan sesudah intervensi.

Hasil penelitian menunjukkan ada perbedaan rata-rata pengetahuan antara kelompok intervensi dengan kelompok kontrol sesudah diberi intervensi ( $p$-value=0,000). Hasil ini memperkuat hipotesis dimana terdapat pengaruh positif SENI terhadap pengetahuan tentang aktivitas fisik penyintas kanker payudara.

Nilai signifikansi sikap pada kelompok intervensi adalah sebesar $(p$-value $=0,000)$, maka dapat disimpulkan bahwa terdapat perbedaan rata-rata sikap pada kelompok intervensi antara sebelum intervensi dengan sesudah intervensi yang artinya ada pengaruh Supportive Educative Nursing Intervention dalam meningkatkan sikap penyintas kanker payudara tentang aktivitas fisik. Sedangkan pada kelompok kontrol nilai signifikansi sikap adalah sebesar ( $p$-value=0,858), hal ini berarti tidak ada pengaruh Supportive Educative Nursing Intervention dalam meningkatkan sikap penyintas kanker payudara tentang aktivitas fisik.

Hasil penelitian menunjukkan bahwa terdapat perbedaan sikap yang bermakna ( $p$ value $=0,000)$ pada kelompok intervensi dan kelompok kontrol sesudah diberi intervensi. Hasil ini membuktikan bahwa terdapat pengaruh positif SENI terhadap sikap penyintas kanker payudara terhadap aktivitas fisik.

\section{Pembahasan}

Berdasarkan tabel 2, dapat dilihat bahwa terdapat perbedaan pengetahuan yang bermakna $(\mathrm{p}=0,000)$ pada kelompok intervensi dan kelompok kontrol sesudah diberi intervensi. Hasil analisis menunjukkan bahwa pemberian supportive educative berpengaruh signifikan terhadap peningkatan pengetahuan penyintas kanker payudara tentang aktivitas fisik. Hal ini dapat disebabkan oleh karena penyintas mendapatkan program supportive educative yang dalam programnya terdapat sesi tentang teaching (pengajaran) tentang aktivitas fisik. Adanya teaching terhadap penyintas dapat menyebabkan peningkatan tingkat pengetahuan penyintas kanker payudara tentang aktivitas fisik. Pemberian informasi membantu meningkatkan pengetahuan dan pemahaman pasien yang merupakan komponen inti dari perawatan diri (Driscoll et al., 2009; Rahayuwati, Nurhidayah, Ibrahim, Setyorini, 2018).

Edukasi suportif SENI dilaksanakan berorientasi pada kegiatan kognitif dan perilaku (Kauric, 2011) sehingga kegiatan yang dilakukan selain memberikan edukasi juga diberikan latihan-latihan peregangan pasca operasi kanker payudara. Kegiatan edukasi suportif ini diberikan dengan berbagai strategi seperti ceramah, diskusi, dan demonstrasi dimana 
penyintas diberi kesempatan untuk melakukan latihan yang telah diajarkan dan penyedian booklet tentang aktivitas fisik sebagai media cetak yang sewaktu-waktu dapat dipelajari pasien. Barnason et al. (2011) melaporkan bahwa intervensi perilaku kognitif secara signifikan meningkatkan pengetahuan perawatan diri serta perilaku manajemen perawatan diri pada pasien dengan gagal jantung (Barnason et al 2011). Bolourchifard et al. (2009) dan Mangolian Shahrbabaki et al. (2012) juga menemukan bahwa edukasi suportif memiliki efek positif pada tingkat pengetahuan perawatan diri pada pasien dengan ulkus kaki diabetik dan gagal jantung (Bolourchifard et al. 2009).

Pemberian edukasi suportif pada penyintas kanker payudara akan semakin meningkatkan pengetahuan serta tumbuhnya motivasi untuk meningkatkan aktivitas fisiknya. Hasil penelitian ini sejalan dengan hasil penelitian yang dilakukan (Mohammadpour, et al 2015) di Iran bahwa ada peningkatan tingkat pengetahuan terhadap perawatan diri pada pasien infark miocardial setelah diberikan edukasi suportif. Hasil penelitian ini juga sesuai dengan penelitian Nurulhuda, (2008) yang menyatakan bahwa pemberian edukasi suportif dapat meningkatkan pengetahuan pasien terhadap mobilisasi dini pasca operasi.

Adanya peningkatan pengetahuan penyintas kanker payudara tentang aktivitas fisik pada kelompok kontrol yang tidak diberikan intervensi kemungkinan karena adanya pengaruh edukasi dokter dan perawat sesuai SOP rumah sakit tentang latihan yang harus dilakukan. Kondisi ini dapat mempengaruhi peningkatan pengetahuan, meskipun ada peningkatan rata-rata pengetahuan kelompok kontrol, akan tetapi masih rendah apabila dibandingkan dengan peningkatan rata-rata pengetahuan kelompok intervensi. Hal ini membuktikan bahwa pemberian edukasi suportif SENI tentang aktivitas fisik sangat berpengaruh terhadap peningkatan pengetahuan penyintas kanker payudara tentang aktivitas fisik.

Hasil penelitian juga menunjukkan bahwa supportive educative signifikan meningkatkan sikap positif penyintas tentang aktivitas fisik. Keadaan ini dapat disebabkan oleh program supportive educative yang diberikan salah satunya adalah guiding, dalam guiding terdapat diskusi dan alternatif pemecahan masalah khususnya pemecahan masalah kurang aktivitas fisik. Adanya diskusi pemecahan masalah dapat meningkatkan kepercayaan penyintas akan alternatif pemecahan masalah yang ada, sehingga supportive educative yang diberikan dapat meningkatkan sikap positif terhadap aktivitas fisik (Darmansyah, Nursalam, \& Suharto, 2013). 
SENI terdiri atas teaching, guiding, dan supporting, dan developmental environment inilah yang menjadi kelebihan edukasi suportif jika dibandingkan dengan edukasi standar. Menurut asumsi peneliti semakin baik pengetahuan dan sikap penyintas kanker payudara terhadap aktivitas fisik, serta adanya bimbingan dan motivasi yang diberikan maka intensitas aktivitas fisik juga semakin baik . Tujuan SENI adalah untuk mempromosikan aktivitas fisik untuk pencapaian kesehatan yang lebih baik. Guiding dan supporting yang dilakukan dapat menjadi sarana yang digunakan untuk mempertahankan dan mencegah individu dari situasi yang tidak menyenangkan atau keputusan yang kurang tepat (Kauric, 2011). Pemberian dukungan kepada penyintas mampu meningkatkan kepercayaan bahwa dirinya mampu menguasai hal melalui pengalaman yang telah dilaluinya atau yang disebut juga sebagai personal accomplishment (Kafil et al., 2018).

Hasil penelitian ini sesuai dengan penelitian Bolourchifard et al. (2009) dan Shahrbabaki et al. (2012) yang menemukan bahwa edukasi suportif memiliki efek positif pada sikap perawatan diri pada pasien dengan ulkus kaki diabetik dan gagal jantung (Bolourchifard et al. 2009). Nurulhuda, (2008) yang melakukan penelitian tentang dampak supportive educative terhadap mobilisasi dalam konteks asuhan keperawatan pasien fraktur dengan fiksasi ekstremitas bawah di RSUP Fatmawati Jakarta diperoleh hasil bahwa intervensi supportive educative dapat meningkatkan sikap pasien terhadap mobilisasi dini pasca operasi $(\mathrm{p}=0.000)$.

Terbentuknya sikap dipengaruhi orang lain yang dianggap penting. Pada umumnya, individu cenderung untuk memiliki sikap yang konformis atau searah dengan sikap orang yang dianggap penting. Kecenderungan ini antara lain dimotivasi oleh keinginan untuk berafiliasi dan keinginan untuk menghindari konflik dengan orang yang dianggap penting tersebut (Azwar, 2013). Dalam hal ini yang mempengaruhi adalah sikap suportif yang diberikan oleh peneliti terhadap penyintas kanker payudara.

\section{Simpulan}

Kesimpulan dari penelitian ini adalah Supportive Educative Nursing Intervention (SENI) memberikan pengaruh signifikan terhadap pengetahuan dan sikap penyintas kanker payudara tentang aktivitas fisik. 


\section{Ucapan Terima Kasih}

Ucapan terima kasih kami sampaikan kepada pihak yang terlibat dalam kegiatan PKM/Penelitian ini, diantaranya :

1. Bapak Prof. Dr. Med. Tri Hanggono Achmad, dr., selaku Rektor Universitas Padjadjaran

2. Ibu Henny Suzana Mediani.,M.Ng.,Ph.D, selaku Dekan Fakultas Keperawatan Universitas Padjadjaran

3. Ibu Yanny Trisyani W.,S.Kp.,MN.,Ph.D, selaku Ketua Program Studi Magister Keperawatan

4. Ibu Dra.Laili Rahayuwati,M.Kes.,M.Sc.,Dr.PH dan Bapak Mamat Lukmat, SKM.,S.Kp.,M.Si selaku pembimbing

5. Ibu Dr. Elsa Pudji Setiawati, dr.,MM, Bapak Ahmad Yamin, S.Kp., M.Kes., Sp.Kom dan Ibu Ermiati, S.Kp.,M.Kep.,Sp.Mat Selaku pembahas.

6. Segenap Dosen dan Tenaga Kependidikan Fakultas Keperawatan Universitas Padjadjaran

7. Seluruh responden, pengelola rumah singgah dan semua pihak yang tidak bisa disebutkan satu persatu

\section{Daftar Pustaka}

American Cancer Society. (2016). Cancer Treatment \& Survivorship Facts \& Figures 20162017. American Cancer Society, 44. https://doi.org/10.3322/caac.21235.

Azwar, S. (2013). Sikap Manusia : Teori dan Pengukurannya (edisi 2). Yogyakarta: Pustaka Pelajar.

Ballard-Barbash, R., Friedenreich, C. M., Courneya, K. S., Siddiqi, S. M., McTiernan, A., \& Alfano, C. M. (2012). Physical activity, biomarkers, and disease outcomes in cancer survivors: A systematic review. Journal of the National Cancer Institute, 104(11), 815-840. https://doi.org/10.1093/jnci/djs207.

Barnason, S., Zimmerman, L., \& Young, L. (2011). An integrative review of interventions promoting self-care of patients with heart failure, 448-475. https://doi.org/10.1111/j.1365-2702.2011.03907.x

Blanchard, C. M., Courneya, K. S., \& Stein, K. (2008a). Cancer survivors' adherence to lifestyle behavior recommendations and associations with health-related quality of life: Results from the American Cancer Society's SCS-II. Journal of Clinical Oncology, 26(13), 2198-2204. https://doi.org/10.1200/JCO.2007.14.6217. 
Blanchard, C. M., Courneya, K. S., \& Stein, K. (2008b). Cancer Survivors ' Adherence to Lifestyle Behavior Recommendations and Associations With Health-Related Quality of Life : Results From the American Cancer Society' s SCS-II. Journal of Clinical Oncology, 26(13). https://doi.org/10.1200/JCO.2007.14.6217

Bolourchifard, F., Neishabory, M., \& AbedSaeedi, Z. (2009). The effects of group and individual education on the level of the knowledge, attitude and practice of self care in patients with diabetic foot ulcer. Iran Journal of Nursing, 22(59), 33-41.

Carmichael, A. R., Daley, A. J., Rea, D. W., Bowden, S. J., Carmichael, A. R., Daley, A. J., ... Physical, S. J. B. (2011). Physical activity and breast cancer outcome : A brief review of evidence, current practice and future direction To cite this version : HAL Id : hal-00638131. European Journal of Surgical Oncology. https://doi.org/10.1016/j.ejso.2010.09.011.

Dahlan, M. S. (2013). Besar Sampel dan Cara Pengambilan Sampel dalam Penelitian Kedokteran dan Kesehatan. Salemba Medika, Jakarta (Kedua). Jakarta: Salemba Medika. Retrieved from www.penerbitsalemba.com.

Daley, A. J., Bowden, S. J., Rea, D. W., Billingham, L., \& Carmicheal, A. R. (2008). What advice are oncologists and surgeons in the United Kingdom giving to breast cancer patients about physical activity? International Journal of Behavioral Nutrition and Physical Activity, 5, 2-5. https://doi.org/10.1186/1479-5868-5-46.

Darmansyah, Nursalam, \& Suharto. (2013). Efektivitas Supportive Educative Terhadap Peningkatan Self Regulation, Self Efficacy, Dan Self Care Agency Dalam Kontrol Glikemik Penderita Diabetes Mellitus Tipe 2. Jurnal Ners, 8, 253-270.

Driscoll, A., Davidson, P., Clark, R., Huang, N., \& Aho, Z. (2009). Tailoring consumer resources to enhance self-care in chronic heart failure. Australian Critical Care, 22(3), 133-140. https://doi.org/10.1016/j.aucc.2009.05.003

Fong, D. Y. T., Ho, J. W. C., Hui, B. P. H., Lee, A. M., Macfarlane, D. J., Leung, S. S. K., ... Cheng, K. -k. (2012). Physical activity for cancer survivors: meta-analysis of randomised controlled trials. Bmj, 344(jan30 5), e70-e70. https://doi.org/10.1136/bmj.e70.

Hancock, C. (2012). Review The benefits of physical activity for health and well - being. Https://Www.C3health.Org/Wp-Content, 2(October).

Kadar, K., \& Patellongi, I. (2017). Compliance Level of Supportive Care Needs Among Breast Cancer Survivor. Indonesian Contemporary Nursing Journal, 1(2), 68-75.

Kafil, R. F., Ropi, H., \& Rahayu, U. (2018). Pengaruh Intervensi Edukasi Suportif Terhadap Kepatuhan dalam Pengontrolan Tekanan Darah Pasien Hemodialisis di RSUP dr. Hasan Sadikin Bandung, 5(Suppl 1), 45-50.

Kauric, K. Z. (2011). Thesis_Improving blood pressure control in ESRD through a supportive educative nursing intervention_Thesis_Read. Nursing.

Kristel, H. F., Anna, A., \& Priambodo, A. P. (2012). Gambaran Pemenuhan Self-Care Requisites pada Pasien Kanker Payudara yang Menjalani Kemoterapi di RSUP dr. Hasan Sadikin Bandung. E-Jurnal Mahasiswa, 1(1), 3499-3504. 
Mohammadpour, A., Sharghi, N. R., Khosravan, S., Alami, A., \& Akhond, M. (2015). The effect of a supportive educational intervention developed based on the Orem' s selfcare theory on the self-care ability of patients with myocardial infarction: a randomised controlled trial, 1-7. https://doi.org/10.1111/jocn.12775

Nurulhuda, U. (2008). Pengaruh Edukasi Suportif Terstruktur Terhadap Mobilisasi Dalam Konteks Asuhan Keperawatan Pasien Fraktur Dengan Fiksasi Ekstremitas Bawah Di RSUP Fatmawati Jakarta. Universitas Indonesia.

Parker, M. . (2005). PART ONE Dorothea E. Orem's: Self-Care Deficit Nursing Theory. Nursing Theories \& Nursing Practice.

Patrick, Pratt, \& Sallis. (2009). The healthcare sector's role in the U.S. national physical activity plan. Journal of Physical Activity \& Health, 6 Suppl 2, S211-9.

Rahayuwati, L., Ibrahim, K., \& Komariah, M. (2017). Pilihan Pengobatan Pasien Kanker Payudara Masa Kemoterapi: Studi Kasus. Jurnal Keperawatan Indonesia, $20(2), 118$. https://doi.org/10.7454/jki.v20i2.478.

Rahayuwati, L., Nurhidayah, I., Ibrahim, K., \& Setyorini, D. (2018). Pendidikan dan Promosi Kesehatan tentang Pencegahan Penyakit Kanker melalui Pilihan Jajan pada SiswaSiswi Sekolah Dasar serta mengenali Potensi Masyarakat dalam Peningkatan Kesehatan. Media Karya Kesehatan, 1(2).

Rock, C. L., Doyle, C., Demark-Wahnefried, W., Meyerhardt, J., Courneya, K. S., Schwartz, A. L., ... Gansler, T. (2012). Nutrition and physical activity guidelines for cancer survivors. CA: A Cancer Journal for Cinicians, 62, 242-274. https://doi.org/10.3322/caac.21142.

Speck, R. M., Courneya, K. S., Mâsse, L. C., Duval, S., \& Schmitz, K. H. (2010). An update of controlled physical activity trials in cancer survivors: a systematic review and meta-analysis. Journal of Cancer Survivorship, 4(2), 87-100 doi:10.1007/s11764009-0110-0115.

Tasripiyah, A. S., Prawesti, A., \& Rahayu, U. (2012). Hubungan Koping dan Dukungan Sosial Dengan Body Image Pasien Kanker Payudara Post Mastektomi di Poli Bedah Onkologi RSHS Bandung. Jurnal Universitas Padjajaran, 1-15.

WHO. (2010). Global recommendations on physical activity for health. Geneva: World Health Organization, 60. https://doi.org/10.1080/11026480410034349.

World Cancer Research Fund. (2018). Recommendations and public health and policy implications. Diet, Nutrition, Physical Activity and Cancer: a Global Perspective. Retrieved from dietandcancerreport.org. 